\title{
The challenges of being a female pastor: A case of the Apostolic Faith Mission in Zimbabwe
}

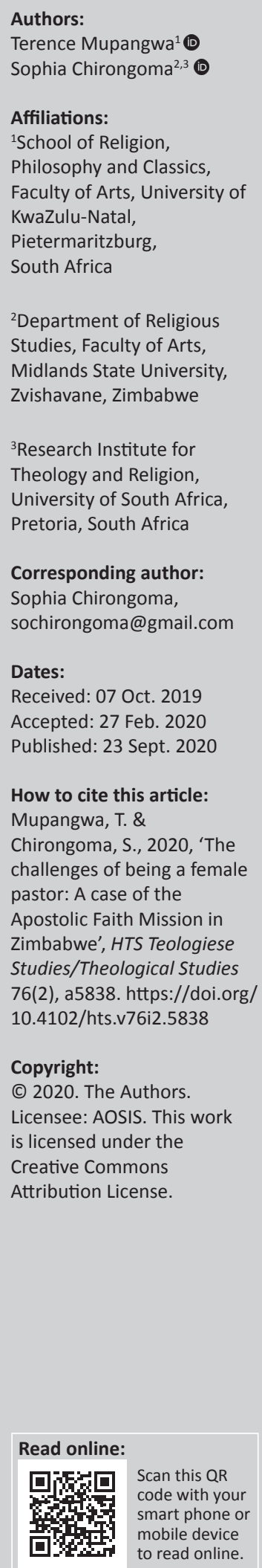

The focus of this article is to highlight some of the inherent gender injustices experienced by the female pastors within the Apostolic Faith Mission in Zimbabwe (AFMZ). Drawing insights from the field research conducted in pursuance of a doctoral programme, the study foregrounds some of the barriers that women have had to endure when it comes to the issue of being ordained as a pastor. The article also interrogates the reasons used as a basis to exclude female pastors from the key decision-making bodies and to deny them the opportunity to preach at the national conference, which is the biggest gathering within the AFMZ. This is a qualitative study utilising interviews, focus group discussions and the observation method. The main findings emerging from this study reveal that whilst some positive changes have been made towards the inclusion of women in the pastoral ministry, however, there are still many gaps needing urgent attention before the AFMZ becomes a gender-inclusive and gender-equitable faith community.

Contribution: This article foregrounds the challenges faced by female pastors in the AFMZ. It advocates for gender mainstreaming and gender inclusive policies in the AFMZ leadership structures. This is in sync with the focus of this collection, for which the main thrust is on women and religious leadership.

Keywords: Apostolic Faith Mission in Zimbabwe; Female pastor; Ordination; Calling; Equality; Justice.

\section{Introduction and background}

This article is a product of the field research conducted in 2017 in pursuance of a doctoral study. ${ }^{1}$ The data were collected before the split of the Apostolic Faith Mission in Zimbabwe (AFMZ) into two. Because of the irreconcilable differences and disagreements over the amendments of the constitution, in 2018 the AFMZ was eventually split into two churches that still use the same designation. As this study was conducted before the split, all the issues raised in this article relate to the AFMZ before the split. The AFMZ is one of the biggest Pentecostal churches in Zimbabwe. According to Ndlovu (2018) and Chivasa (2017), the AFMZ is the mother of Pentecostalism in Zimbabwe. Despite being the mother of Pentecostalism in Zimbabwe, however, the AFMZ took a really long time before opening up the doors of opportunity for women to be ordained as pastors. Other Pentecostal churches such as the Zimbabwe Assemblies of God Africa (ZAOGA), which is an offshoot of the AFMZ, began to ordain women well before the AFMZ accepted it (Togarasei 2016:5). The AFMZ only began to ordain women in 1999 after a white woman from the AFM in South Africa attended the AFMZ's annual general conference at Rufaro as an ordained minister in Africa (Kwaramba 2019, 2004). During the conference, this white woman, popularly known as Diagar's daughter as if she did not have a name of her own, attended 'Dare raana baba' (the men's Apostolic council), which is the highest decision-making board in the AFMZ. Paradoxically, it was regarded as a taboo for Zimbabwean women to attend such a prestigious council. ${ }^{2}$ Leadership in the AFMZ since its inception was a preserve for men. Even after the concession to accommodate women into the ordained ministry, the Apostolic council is still constituted by men that is why it is still being referred to as 'Dare raana baba' (men's apostolic council). After she had attended the Apostolic Council that is when the then leadership of the time through the guidance of President Mutemererwa decided to ordain female pastors in Zimbabwe as well. According to Kwaramba $(2019,2004)$, President Mutemererwa argued that if the AFM in South Africa had already ordained women, then nothing could stop the Zimbabwean women from being ordained as well.

\footnotetext{
1.Terence Mupangwa (2019)
}

2.It was observed during the interviews that no one seems to know the name of this woman. Everyone referred to her by his father's name (Diagar's daughter). This perpetuates the patriarchal and androcentric worldview whereby women are identified through their male relations. 
Consequently, from that time onwards, the AFMZ began to ordain women (Kwaramba 2004; Murefu 2008). According to church records accessed in 2017, there are 46 ordained female pastors. However, the female pastors who participated in this study highlighted that although the church is allowing women to become pastors, they felt as if this move had not been adopted with an open and genuine heart because female pastors are still facing numerous operational challenges. They all concurred that it has not been an easy road for most of the female pastors in the AFMZ. It is against such a background that this article focuses on outlining the challenges faced by female pastors in the AFMZ.

\section{Literature review}

The status of women in general remains a topical issue in the study of religion. This is evidenced by a number of scholarly papers that have been written concerning the place of women in different aspects of religion. Studies on women and church leadership, as well as women and HIV and AIDS in the church (Chirongoma 2019; Kwaramba \& Dreyer 2019; Chitando 2013; Biri 2013; Nadar 2005), show that women have not been accorded equal treatment in religious circles. Darko (2015) postulates that:

$[B]$ being ordained, a member of the church is publicly affirmed as being called into service of Christ and usually such a person is viable for any leadership position within the ecclesiastical structure. (p. 38)

One thing that comes out clearly from what Darko (2015) says is that ordination is all about serving. However, when some of the ordained pastors, particularly the female pastors, are exposed to a lot of challenges, it becomes an uphill task for them to serve. There is therefore need to reiterate and acknowledge that women were also created in the image of God because they also contain the Spirit of God thus making them living souls. This means that they are rational and creative and they understand morality. Hence, instead of subjecting female pastors to the challenges they are currently going through, they must be accorded the same rights with their male counterparts. Responding to the restrictions imposed upon women in some churches, especially during their menstrual cycle or soon after giving birth, Oduyoye (1995) queries those who argue against the ordination of women by stating that women 'serve at the table' at home despite their condition but are hindered to 'serve at the table' in the church. In essence, Oduyoye is saying that if women can serve you anywhere else, why not in the church? It is therefore unjust to treat female pastors indifferently simply because of their gender.

The AFMZ is still struggling to accommodate women as pastors, and yet, some scholars such as Muringa and Makaudze (2014), Machingura and Nyakuhwa (2015) and Makaudze (2014, 2015) contend that African culture, particularly the Shona culture, is not restrictive to women. They cite several examples to illustrate that the African culture is flexible enough to allow women to be in leadership. According to Muringa and Makaudze (2014), the true Shona culture, which is the culture before the coming of the missionaries and colonisers, does not bar women from taking up leadership positions. They argue that gender roles in the Shona culture are fluid and not fixed such that women can freely take up leading roles. Similarly, Machingura and Nyakuhwa (2015) contend that women in the African milieu were empowered and respected. According to these scholars, women could become spirit mediums, and queens were highly respected as well as mothers and aunts. Machingura and Nyakuhwa (2015) argue that in all situations or occasions where women are sidelined or treated with little respect, it is not a true reflection of the real African culture. African scholars have noted how women have been sidelined in many aspects of life using culture as a scape goat. On the other hand, scholars such as Nadar (2005) and Dodo, Dodo and Zihanzu (2017) are of the opinion that culture is one of the conspirators against women's flourishing in the society. According to them, the African culture is restrictive and is not life affirming to women. Nadar (2005:17) in her article 'Searching the dungeons beneath our religious discourses: The case of violence against women and the "unholy trinity"' reflects on the unholy trinity of religion, culture and gender. She argues that these three aspects work in unison to make sure that women do not progress in life. As a result, female pastors in the AFMZ are facing challenges in their work in ministry.

The church is supposed to be a safe place for all its members, which means that it should be a place where women feel that they are accepted as who they are. This also implies that the church must become a safe and inclusive space where women feel that they are an integral part of the community of believers. They must neither feel judged, looked down upon nor discriminated against. If any church members are to face any criticism, it has to be constructive criticism for the church to continually be a safe haven for its members. When members continually receive negative feedback, the environment becomes unpleasant and they cannot boldly identify themselves as such, hence a loss of the sense of belonging. In the church, women are often marginalised and oppressed. Russell (2001) contends that women are looking for a place which they can call home and feel welcome. Writing about feminist ecclesiology, Watson (2002) reiterates that women should be able to name themselves as the church. They can only name themselves as the church if it becomes a safe place for them.

There is a tendency among some church going people to consider the clergy as the true church. Oduyoye (2005:151) is of the view that everyone ordained or not is the church. Therefore, everyone in the church should be recognised as a deserving member. Feminist ecclesiology is a theology that advocates for a church in which everyone feels safe and can call it their home. Currently, the AFMZ as we know it is not a place which female pastors can unanimously call home. The general assumption would be that because they are pastors and leaders of the church, they feel safe in the church. Unfortunately, the experiences of the female pastors in the AFMZ are far from this ideal. As such, this article focuses on highlighting some of the challenges that female 
pastors are facing in the AFMZ in a bid to show that currently the church is not a safe place for them.

There has been scholarly debate in the academic fraternity over the question of whether women should be ordained or not. According to Darko (2015:38), it is apparent that there is no agreement within the church concerning the issue of the ordination of women. Similarly, Clifford (2001:140-148) highlights that even feminists are also debating over this issue. She also notes that some feminists do not believe that the ordination of women will get rid of the hierarchical structures within the church; therefore, they do not see the discussion and the advocacy for the ordination for women being of value. Rakoczy (2004) and Phiri (1997) advocate for the ordination of women in order for them to access leadership positions in the church. According to Oduyoye (2001:72), the death of Christ brought equality between men and women; therefore, there should be no discussion on whether or not women should be ordained at all. She asserts 'Christian women find it unacceptable that we continue living as if Christ never died'. This means that the death of Christ brought freedom to all humanity to be all they want to be including being ordained ministers. Consequently, the death of Jesus should have brought forth liberty for the whole human race including the unshackling of chains still binding women from enjoying absolute freedom in some churches.

\section{Theoretical grounding}

This article is grounded on the principles derived from African women's theology. African women's theology advocates for equality and justice between men and women. African women theologians interrogate why worldwide women have been treated as 'outsiders' in the church (Sprong 2011). According to Sprong (2011) and Kanyoro (2001), God's original intention at creation was for men and women to reign as equals in their dominion over creation. African women theologians argue that if men are working alone in leading the church, this will be reminiscent of a one-winged bird that cannot fly properly (Oduyoye 1990:27). According to Oduyoye (2001:17), African women's theology is a theology of relations replacing hierarchies with mutuality. Hence, African women theologians unequivocally advocate for women to be included in church leadership so that it becomes a two-winged bird that can fly properly. They conclude that men and women should work together to complement each other. Such complementarity and collaboration will remain a pipedream if women continue facing a lot of challenges because they will not be in a position to work and complement men effectively.

African women theologians also advocate for scripture to be read from a perspective that empowers women (ed. Dube 2001; Gabaitse 2012). It is a hermeneutic that challenges the traditional theology which defined a person from a patriarchal male experience (Oduyoye 2000:191). According to Kanyoro (2004:viii), the dominant theme in the bible is justice and it has to be extracted and be used to eradicate the marginalisation and victimisation of women in the church. She went on to add that a critical reading of the bible assists the church to challenge structures that perpetuate the subjugation of women. This theology liberates both men and women from all forms of oppression (Hinga 1992; Sprong 2011). African women's theology also emphasises the pertinent need for women to tell their own stories; hence, this study draws from the AFMZ female pastors telling their own stories of struggle and tenacity amidst the throes of patriarchy.

\section{Feminist ecclesiology}

The major proponent of this theory is Watson (2002). Feminist ecclesiology grapples with the task of defining the meaning of the terms 'church'. Watson (2002) states that feminist ecclesiology empowers women and assists them to name and define the church. It is a theology that recognises women as the church (Radford Ruther 1996). The church is not supposed to be stratified as it is today and women cannot safely call it a home (Letty Russel 1987:67). The bible does not portray a hierarchical church; instead, it carves an image of disciples of equals (Rakoczy 2004:199). This theory is suitable for this study in that it empowers women and helps them to question the prevailing status quo in the church. In this study, the tenets of feminist ecclesiology will be used to examine and analyse the practices of the AFMZ in relation to women leadership. It will also be used to consider the responses of the participants from a narrative perspective.

In view of the fact that the focus of the study is an African church, particularly women's experiences in that particular church, African women's theology and feminist ecclesiology are relevant for this study because it seeks to investigate the challenges faced by female pastors in the AFMZ. Although Haddad opines that the Manyanos are a safe place for women, conversely, the prevailing challenges encountered by the female pastors in the AFMZ has led them not to view the church as a safe place to be. This implies that if the church becomes gendered, then it ceases to be a community (koinonia). African women theologians also advocate for equality and justice for both male and female pastors so that they feel and know that they all belong to the church. It is also relevant for this study because it is premised and rooted in African culture and world-view which is seemingly a principal driver for the treatment of female pastors in the AFMZ. As it focuses on women in the context of African philosophy and way of life, it, therefore, becomes a useful resource in interrogating the experiences of female pastors in the AFMZ.

\section{Methodology}

The study is predominantly qualitative in the sense that interviews and focus group discussions were the data collection tools. This study was carried out in the cities of Harare, Mutare and Bulawayo, targeting 60 members of the AFMZ who were purposefully sampled. Interviews using unstructured interview questions were conducted with 10 female pastors and 10 male pastors, 2 deacons, 2 elders, 3 elderly women beyond the age of 70 and youths in the AFMZ. Four focus group discussions were conducted with four committees of four departments in the AFMZ, namely the 
Sister's Union (Ladies department committee), a local church assembly board (constituted by married men), the boys' fellowship (boys' youth group) and girls' fellowship (girls' youth group). The age range of the participants was from 18 to 85 years. Engaging in a discussion with the Sisters' Union was deemed important because it opened up opportunities for listening to the views of married women. The married women's voices are instrumental in shaping the thrust of this study. In addition, the male-dominated main church board of the local assembly was an important source of information in that it provided the perspective of married men as well. More so, the views of the youth were also important; hence, input was sought from the boys' fellowship and the girls' fellowship. Ten female pastors and 10 male pastors were purposefully sampled. Unstructured interview questions were used to extract information from the participants. The studied participants were from different cities and backgrounds; therefore, the results can be said to reflect the general trend in the AFMZ. The thematic method of analysis was primarily used in analysing the qualitative data gathered in this study. Having read the transcribed document carefully, manual coding was done with the view to generate a logical and understandable analysis (Reynolds 2012:106).

\section{Findings}

During the interviews, all the 10 female pastors revealed that one of the common challenges faced by female pastors in the AFMZ is that of being overshadowed by the pastors' wives. Although most pastors' wives are not pastors, however, they are the ones in charge of leading the ladies' department. Consequently, female pastors have lost the grip on leading even the women's departments which is supposed to be their preserve in light of the hierarchical patriarchal structures in the church. The female pastors who participated in the study echoed the sentiment that the pastors' wives have literally usurped the leadership of the ladies' department simply because they are married to the pastors. Hence, indirectly, the male pastors have the overall control of the women's department because their views are propagated for by their wives. The pastor's wife is the one who preaches at the national and provincial ladies' conferences and not the female pastors. The assumption is that by being a pastor's wife, she automatically becomes a leader who is called into ministry together with her husband. It would therefore appear as if church leadership and being called into ministry is sexually transmitted in the same manner that Robert Mugabe, the former president of Zimbabwe, wanted to impose his wife Grace Mugabe to take over the presidential seat from him, something which the general populace strongly resisted leading to him being ousted from power in November 2017. In the case of the female pastors in the AFMZ, the proper and logical procedure would be that they be given an opportunity to preach at the national and provincial ladies' conferences as well.

This would address the prevailing anomaly whereby the pastors' wives have taken over the leadership of the ladies' department and the female pastors have since been pushed into oblivion. What is even more paradoxical and illogical is the fact that the female pastor often has to report to the pastor's wife, for example, in the case of female pastors who were appointed to lead or oversee activities of single and widowed women in the church.

Another challenge that was highlighted during interviews with all the 10 female pastors, 5 male pastors and 3 elderly women related to the constant clashes between female pastors and the pastors' wives. It was also noted that these clashes are mainly caused by an ensuing power struggle and a blurring of lines in terms of power structures between the two groups. The pastors' wives are of the view that they should be accorded more respect than the female pastors. This is influenced by the perspective that the female pastors occupy a lower pedestal as compared to the male pastors regardless of the fact that they are all pastors holding the same office. Hence, the inferior status ascribed to the female pastors is used as a vantage point by the pastors' wives to disregard their leadership rights and capabilities. Consequently, the female pastors are of the view that the pastors' wives do not support any initiatives spearheaded by a female pastor. Two female pastors mentioned that pastor's wives do not support projects initiated by female pastors, if anything, they would rather sabotage the projects. One of the pastors' wives who participated in the Sisters' Union focus group discussion contended that the female pastors should know that pastors' wives exist; hence, they should not just come and implement projects without first consulting with them even if it is an assignment coming from the provincial or national level.

For example, two female pastors described the clashes that they had with the pastors' wives when they were given the responsibility of being the leader of the single and widowed women. Usually, the pastors' wives feel that the female pastors do not accord them the respect that is because of them. Therefore, they usually have clashes over very petty issues. For example, it was revealed that whenever the female pastor needs the help of the pastor's wife to implement a certain project, that is, when she exercises her power and influence to sabotage the project. Two of the female pastors shared their experiences of leadership wrangles with the pastor's wife after having been assigned to lead the department for widowed and single women. They said that they organised fundraising functions for all women in different assemblies to participate in, but the pastors' wives sabotaged the functions. For example, one of the female pastors bemoaned how the fundraising dinner event she had organised in order to raise money for the widowed and single women was sabotaged by the resident pastors' wives. She added that after having distributed the tickets for the dinner to be sold to the members of the assemblies in the province through the pastors' wives, she was disheartened to learn that the pastors' wives had not made an effort to sell the tickets. Unfortunately, the female pastor who had organised the event came to this realisation only a few days before the planned date for the dinner. The excuse given by the pastors' wives was that they reckoned that the members of the 
different assemblies were overwhelmed with other church programmes that required money; hence, they decided not to advertise the fundraising dinner event. As the pastor's wife is the head of all women's departments at the assembly, provincial and national level, it naturally follows that the female pastor has to report to the pastor's wife. One of the female pastors explained that when she was applying to train as a pastor, the pastor's wife was a hindrance to her application process. She described how the pastor's wife would tell her bluntly that she would make sure that the pastor does not sign the recommendation letter for her because she did not want another woman to occupy the same position as her husband. The fact that the pastors' wives do not want other women to become pastors because they will be at the same level with their husbands was a recurring issue raised by most female pastors.

During the interviews and focus group discussions, all the female pastors lamented the fact that they took longer to be placed than their male counterparts whom they graduated with. Five male pastors also echoed the same sentiments during the interviews. They related incidents whereby the overseers in the provinces make sure that all the male pastors are allocated assemblies first. Once the available assemblies have all been taken by male pastors, the overseers do not even make an effort to ensure that the female pastors have something to do. They are just left to rot and the overseers will be hoping that they will give up and leave the pastoral work. All the female pastors who participated in the study explained how they had to make constant follow-ups but all in vain. As a result, all of them had to take the initiative to start their own assemblies from scratch in order to prove their calling. The experiences shared by these female pastors clearly revealed that they are encountering mounting trials and tribulations in their ministry. They also added that if they fail to please their superiors, they will not be assigned as the pastor of the assembly which they set up. Another discrepancy noted by the female pastors is the fact that male pastors in the AFMZ are no longer going through the probation period whereby they will be under a senior pastor. Conversely, if the female pastor is assigned an assembly, she will be stationed in the rural areas, whilst all the urban areas are allocated to the male pastors. The major challenge is that in the rural areas, the congregants are not able to provide for the pastors financially unlike in the towns. One of the female pastors complained that she has served for more than 17 years but she is still stationed in the rural areas and yet junior male pastors are being stationed in urban areas.

All the female pastors pointed out that most overseers doubt their call. They still question whether God can truly call women into ministry. The overseers publicly announce that they do not believe that women are called to become pastors. Even during the training period, some of the overseers who are lecturers at Living Waters Bible College would openly express these segregatory and sexist views during lectures. Some of the overseers do not assign assemblies to female pastors because of this belief. The study participants also highlighted that some overseers do not even want female pastors in their provinces because they do not believe that women can be called to become pastors. The few overseers who accept the female pastors in their provinces will ask them to prove their call by planting an assembly usually in the rural areas, a requirement which does not apply to the male pastors.

They also highlighted that after fully establishing an assembly, the male pastors will be assigned to take over the leadership of that assembly and the female pastor will be instructed to establish another assembly. Another unfair and unjust trait endured by female pastors is the fact that they are always being transferred from one station to another. They explained that some male pastors envy their assemblies because of the progress taking place and they connive with the overseers for them to take over the assembly. One of the participants narrated how she suddenly found herself being served with a letter instructing her to transfer to another assembly after a male pastor had been appointed to lead her assembly. They also highlighted that usually the standards fall the moment the male pastor takes over the assemblies which used to flourish under the leadership of a female pastor.

The other challenge they face is being sidelined in the church leadership. The focus group discussion with the boy's fellowship and girls' fellowship pointed out that men are the ones who hold all key leadership positions and leadership is believed to be only for men. During the focus group discussions with members of the Sisters' Union, the study participants also mentioned that there is no female pastor who has been a president or overseer of the church. Madziyire and Risinamhodzi (2015) and the church website list the presidents and overseers from the time the AFMZ was weaned from AFM South Africa. They pointed out that it seems as if the posts are specifically for male pastors. The constitution of the church uses the pronoun 'he' for these positions (AFMZ constitution Chapter 9, Section 9.4.1).

Eight out of 10 female pastors also highlighted that they face the challenge of unsupportive husbands, especially during the initial stages of their pastoral work. They bemoaned how some husbands are not supportive, especially during the most crucial times, when they need their spouses to show solidarity. For instance, they explained that the moment the female pastor faces challenges or difficulties in the church, the husband usually advises her to quit even if she feels that she has to fight on. They added that usually, the husbands become supportive when the dust has settled down. As such, they normally find themselves between a rock and a hard place because on many occasions, the female pastor has to choose between the church and her husband. The good news is that none of them have given up on their calling, they have continued to serve the church against all odds.

Another challenge and disappointment bedevilling the female pastors is that they are not given an opportunity to preach at national conferences. It is only men who preach at 
Rufaro AFMZ's national conference centre in Chatsworth Masvingo. It is at Rufaro that all national conferences are held, that is, the youth, ladies' and the general conferences. During these conferences, only male pastors are allocated slots to preach, even serving as the Masters of ceremonies in the programme is a male preserve. Sometimes male church elders who are the laity are asked to preach at these conferences but the opportunity is not availed to female pastors.

Another impediment to the female pastors' growth is the fact that they face victimisation whenever they show interest in joining the leadership of the church. One of them narrated the ordeal she went through. She explained that the moment she started contesting for a higher leadership post, she was victimised by turning board members against her and being transferred from one assembly to another. The overseer also made sure that she stayed in the rural areas because he accused her of being disrespectful. She explained that by merely contesting for the post of an overseer, she was branded a traitor. The overseer even reminded her that she was supposed to be grateful that he had allowed her to serve in his province. She explained that since then, she feels so intimidated such that she has become very much afraid to cross the path of the leaders.

During the focus group discussions with the Sisters' Union and the girls' fellowship, one other challenge that was highlighted which female pastors are facing is that the church leadership is encouraging their husbands to enrol in bible schools so that upon graduating from the bible school, the husbands will take over the assemblies they are leading and then they will have to revert to the position of a pastor's wife. The female pastors said that the leaders will come and give an order that in the AFMZ, if both husband and wife are pastors, then the wife is expected to step down so that the husband will take over as the pastor of the assembly. The study participants in the Sisters' Union and three female pastors related the story of one female pastor who eventually started her own ministry after the husband was ordered to take over her assembly after they encouraged him to train as a pastor as well. During the focus group discussion with the girls' fellowship, they also narrated the story of a female pastor who is facing a hard time with the elders of the assembly who were adamant that they cannot be led by a woman. They explained that whenever this female pastor calls for a meeting, the board of elders intentionally abscond the meeting. They also added that sometimes the church elders do not attend the church service on Sunday as a sign of protest and to restate the message that they do not want to be led by a woman. The study participants also revealed that these church elders were busy coercing the husband of their female pastor to also join the bible college and train as a pastor so that they would find an excuse for pushing the female pastor out of their assembly. Once her husband has graduated from the bible college, the female pastor has to step down from her pastoral position to become a mere pastor's wife even though she has been called to become a pastor in her own right. Because of this, the female pastors expressed disappointment over the fact that the top leadership and some male pastors are encouraging their husbands, who may not have been called at all to jeopardise their call. However, they were suggesting that in a situation whereby the husband truly has a calling and he becomes a pastor as well, they should be assigned separate assemblies that are close to each other so that their ministries will not put a strain on their marriages.

Another hurdle faced by the female pastors is the fact that some male pastors want to take over their assemblies, and in several instances, they have actually taken over the assemblies. They explained that this is because of the fact that most of the female pastors are leading their assemblies so well such that there is growth spiritually, numerically and materially. Once the membership increases, the assembly also begins to flourish spiritually because the female pastors allow the congregants to participate in church, leading them to grow spiritually. The congregants also tend to flourish materially such that they can afford to substantially bless their pastors as well. As such, some of the female pastors are now owning the latest car models and nice houses which they have acquired through hard work both in the church and outside church activities. All these achievements have ignited envy from some of the male pastors to such an extent that they want to take over the assemblies. The female pastors also mentioned that usually when the male pastors take over these assemblies, there has been a trend that such assemblies suddenly begin to experience a downward spiral in terms of growth.

\section{Ethical considerations}

Ethical approval to conduct the study was obtained from the University of KwaZulu-Natal, Humanities and Social Sciences Research Committee (reference no. HSS/026/017D).

\section{Discussion Being overshadowed by the pastors' wives}

By making the pastor's wife more superior to the female pastor, the church is subtly perpetuating patriarchy. This is because the pastor's wife is elevated to become a leader simply because her husband is a pastor whilst the female pastor is perceived as inferior because her husband is neither a pastor nor a leader in the church. Clearly, this gives the impression that the pastor's wife is a more deserving member of the church than the female pastor because she is married to a male pastor. The fact that usually the husband of the female pastor is not given any key leadership role by virtue of being married to a female pastor evidently illustrates the structural patriarchal stereotypes and policy inconsistencies within the AFMZ. African feminist theologians such as Oduyoye (2001) relentlessly critique such retrogressive and unjust patriarchal practices.

What the AFMZ leadership seems to be oblivious of is the reality of the fact that everyone is equal before God because we were all created in the image of God. African women theologians have also been raising a clarion call against 
clericalism. According to Watson (2002), the clergy is only part of the church. The clergy has to acknowledge that they cannot operate in the absence of the laity. In view of this, female pastors should not feel that leadership is only for them because they were called. They should feel comfortable working with the laity as well and being under them in certain circumstances. In that way, everyone who deserves to lead should be given the chance. Diversity is required in the church. This creates a balanced community. Shaw-Taylor (2013:10) supports these views by arguing that church leadership does not only belong to men, but to all who can prove to be worthy of the positions. In her illustration, Shaw-Taylor uses an African proverb 'no tree can form a forest' to illustrate that, there is need for representation of both men and women in the leadership hierarchy. A further exploration of the African proverb regarding the formation of a forest denotes the fact that in the same manner that a thriving forest is seen through the diversity of vegetation within it; therefore, a balanced and thriving leadership should also be diverse in its composition. Applying this principle to the church therefore suggests that for diversity to be celebrated and for progress to be attained, there is need to respect the humanity and dignity of all humanity created in God's image. Such an understanding would then provide a platform for the pastors' wives to appreciate that the female pastors have a superior calling than them in the sense that they are actually pastors, whilst on the other hand, the pastors' wives are simply married to pastors. This modest acknowledgement will probably lead to the pastors' wives embracing the apparent fact that the female pastors have the same anointing as their husbands. Although Martin Luther and other church reformers proclaimed the priesthood of all believers and the bible (Eph 4:11-13) also articulates the calling of believers to the fivefold Ministry, which is the calling of the prophets, pastors, teachers, apostles and evangelists, however, female leadership in most ecumenical circles is still a contested issue. This leads to the conclusion that whilst we are a royal priesthood, there is a separation and difference with those called into the fivefold Ministry. In this light, the roles of a pastor's wife should be clearly stated to give room for the female pastors to be treated as equals with their counterparts, the male pastors.

\section{Clashes with the pastors' wives}

What has been presented above could be an illustration of the fact that the pastors' wives are experiencing an insecure complex and they are probably jealous of the female pastors' positions. All these feelings create unnecessary animosity and provide a fertile ground for an unpleasant environment within the church. The church should be a community of love and unity where all members support each other. The attitude of the pastors' wives also seems to suggest that they believe that men are the only ones who should be leading the church. The fact that the pastor's wife is automatically made a leader of the ladies' department simply because she is married to a male pastor shows that her position of leadership is just but an appendage of her husband's. Instead of female pastors and pastors' wives clashing, they should rather forge a united front and work in unison because they all have the church's best interests at heart. Once they have managed to reconcile their differences and have started working in solidarity, the church will become a safe place for both the pastor's wife and the female pastors as well as other members of the congregation who are constantly roped in the ensuing opposition and clashes. If such tensions are amicably addressed, this will probably eliminate some of the prevailing divisions in the church. One of the root causes for such disunions is the fact that some church members will be supporting the pastor's wife, whilst others will be supporting the female pastors. This may result in unnecessary chaos, confusion and a lot of gossiping amongst the church members. All this turns the church into a hostile and unpleasant place. However, with enough effort to resolve the differences and tensions between the pastors' wives and the female pastors, the church becomes a safe place, providing sanctuary for all the saints.

As noted by Muringa and Makaudze (2014), in the traditional Shona culture, women would support each other and not pull each other down. Clearly, what is happening in the AFMZ is an antithesis of the true Shona culture. The tussling and tiffs between the pastors' wives and the female pastors are reminiscent of the Shona proverb which states that two bulls cannot be in the same kraal, suggesting that they cannot stand each other such that they end up fighting. The same also pertains when two women are sharing the same kitchen. The conflict and squabbles of who is in charge are always visible. Hence, African women theologians have tried to come up with resources for forging unity and solidarity amongst women by creating platforms for partnership and networking such as the formation of the Circle of Concerned African Women Theologians (the Circle). Oduyoye (2001) who is the brainchild of the Circle laments how some African women have internalised the subjugation of women such that they have become accomplices in the suppression of their own gender. It is in response to such internalised oppressions that members of the Circle are making efforts to conscientise each other, foster dialogue and reconciliation.

When female pastors take a long time to be appointed at an assembly, usually, it negatively affects their effectiveness in their work. This is because delaying to have an assembly to lead implies that they will be delayed in getting an opportunity to put into practice the theoretical knowledge and skills they would have learnt at the bible college. It also affects them in the sense that the male pastors will always qualify first for top leadership positions because the requirement for promotion is that one should have served for a certain number of years in ministry. All these barriers faced by female pastors in the AFMZ are a reflection of the influence of both African traditional patriarchy and western patriarchy.

\section{Overseers doubting their call}

It is wrong for the overseers to doubt that the female pastors have a genuine call to minister in God's mission field. Everyone was created in the image of God, as such, God 
calls anyone in spite of their gender. God calls people to serve and not to exercise power over the members of the church. Male pastors want to be completely above women because they do not understand that they are called to serve. If everyone understands that they are vessels and are expected to serve, they will not hinder the other person by doubting their call. In fact, it should be a joy that the Lord is increasing the labourers for the harvest is plenteous as Jesus stated in the gospels (Mt 9:35-38; Lk 10:2). Women are equal co-labourers in the work of the lord, and therefore, their call should not be doubted. This is also echoed by Kanyoro (2001) who reiterates that:

\begin{abstract}
African women theologians encourage the inclusion of women pastors into ordained ministry in order to create an opportunity for women pastors to be pillars for establishing mutuality with women in the congregations. This, they maintain would make it possible for women to be included in the telling of the story of faith to the community of faith. (p. 68)
\end{abstract}

\section{Assemblies being taken over}

Several Shona myths and folktales portray women as weak, whilst men are presented as natural leaders. This could be one of the main reasons why the AFMZ propagates for male pastors to take over what the female pastors would have worked for. Critiquing the inherently skewed and maledominated ecclesiastical leadership structures, Oduyoye (2004:88) argues that 'God cannot be said to have brought into being one variety of humanity that is inherently not up to the mark'. This study has revealed that women are also capable of leading and this has demystified the myth that only men are natural leaders. The male pastors who are envious of the thriving assemblies led by women need to realise that it is God who enables through the Holy Spirit. Therefore according to Oduyoye (2004), whatever is keeping the subordination of women alive in churches cannot be the Spirit of God. The truth of the matter is that the female pastors are being successful in establishing assemblies and have the members grow, numerically, spiritually and materially through the power of the Holy Spirit. The same power which has made male pastors successful is the same power that is enabling female pastors to flourish. Besides, in the church, there must prevail reciprocity and mutual respect, support and protection of each other (Oduyoye 2004). African women theologians advocate that the church should empower women not only to speak for themselves or manage their own affairs but to be fully present in decision-making and operations that will affect the whole. Oduyoye (2004:90) says that 'when we find patriarchal hierarchies enthroned in the place of worship, we must begin to wonder if we are not closing our eyes and ears to the truth revealed by the Spirit of God'. She went further to declare that when women aspiring to be in leadership are viewed as rebellious and are not supported, we can suspect the Spirit of God is being ignored.

\section{Being sidelined in the church leadership}

There may be a number of reasons behind why women are being sidelined in the AFMZ leadership structures. In her paper entitled 'Searching the dungeons beneath our religious discourses: The case of violence against women and the "unholy trinity"', Nadar (2005) tenders that the unholy trinity of religion, gender and culture unveiled may be responsible for this marginalisation of women. Being nonmale imposes a penalty on women simply for not being born in that group which is held to define true humanity. According to Oduyoye (2004), the power to define oneself as true humanity is an awesome power. A person who is defined by others can only go as far as he or she is allowed to go. This is how injustice develops. Patriarchy is also inevitably at work in this church. African feminist theologians such as Oduyoye (2001), Phiri (2004) and Kasomo and Maseno (2011) vehemently critique a patriarchal mindset which perceives men as natural leaders. Hence, African feminist theologians advocate for cultural and religious practices that are life affirming to women. According to Oduyoye (2004), the church must deal with patriarchy if it is to succeed in empowering women and men to celebrate each other. If the AFMZ doctrine professes to be in obedience to God's leading, there is need for the leadership to repent and confess of the sins of omission and commission. The male-dominated leadership must acknowledge that denying women access to top leadership positions as well as sidelining female pastors in the leadership hierarchy are both sins of commission and omission. They are clearly disobeying the will of God for humanity; therefore, they need to awaken from their slumber and make things right by observing gender justice in the church. African women theologians also propound for an intentional reading and application of biblical texts endowed with a message which is life giving, inclusive and liberative. In this light, Oduyoye (1995) contends that if churches believe in the scriptures, then either women and men are equal or we declare Genesis 1:26 a lie. According to Genesis 1:26, both men and women were created in his image. Hence, Oduyoye (2004) reminds us that for Christianity to be authentic, it should uphold interdependence of unique individuals and promote inclusiveness.

\section{Unsupportive husbands}

As has been noted above, some of the female pastors bemoaned that whenever they were experiencing challenges in their ministry, their husbands did not offer them the much needed support and encouragement. By being not supportive to their wives, the husbands of the female pastors make the work of female pastors a lot more difficult. This shows that the challenges encountered by the female pastors are starting from their homes and climax in the church. If equality starts in the home, that will also influence practices in the church. There is an interplay of culture, religion and class in this situation which is referred to by Nadar (2005) as an unholy trinity. Culture has relegated the woman to an inferior position than the husband. Adding salt to the wound, her gender and religion go on to cement this practice by upholding patriarchy through verses like Ephesians 5v 22-33 and 1 Peter $3 \mathrm{v} 1$. These verses emphasise on women submitting to their husbands, and most conservative 
Christian communities have come to interpret this to mean that a woman should always be under a man. In view of this, Oduyoye (2004) argues that Christianity and colonisation did not create patriarchy but both strengthened it. According to Oduyoye (2004), before the advent of both Christianity and colonisation, the African culture served as a surrogate patriarchy. However, culture is not static. Although culture is sometimes viewed as something that is imposed upon people, it is actually the creation of people themselves. People can thus create and recreate culture in order for it to be continuously life giving, especially to women. Charity begins at home, by the same token, as long as female pastors are perceived as having a lower status than their spouses at home, it becomes very difficult for them to flourish as pastors. The idea of complementing and seeing each other as equal is vital in the home environment. Husbands and wives are expected to support each other, especially if they are Christians.

\section{Victimisation}

The fear of victimisation means that the female pastors are always operating in fear of intimidation and ostracisation. This makes the AFMZ not a safe place such that the female pastors can barely call it a safe home. Victimisation instils fear in people and stifles their growth spiritually, physically and emotionally. Oduyoye (2001) avers that women see the church as divided against itself as long as it militates against them. According to Russell (2001:48), women suffer violence in the church, whereas the church is supposed to be a safe space offering them protection from such vices. She went further to use the metaphor of a 'hot-house' used in Japan to refer to a place where women can feel protected, safe and accommodated (Russell 2001). It is, therefore, unfortunate that currently women in the AFMZ do not see the church as a 'hot house'. As emerged from the views raised by the study participants whose voices are a foundational resource for this article, women in the AFMZ currently view the church as a place where they are downtrodden, suppressed and marginalised. Such negative experiences culminate in destroying their confidence, consequently posing a hindrance for any aspirations to rise up the leadership hierarchy. Hence, intentional efforts must be made to turn the AFMZ into a safe and welcoming space for both men and women of faith.

\section{The church leaders' ploy to strip female pastors of their positions and turning them into pastors' wives}

This twisted idea of turning female pastors into pastors' wives by hoodwinking their spouses to train as pastors may be an influence of socialisation that only males are supposed to become pastors. As such, the current AFMZ leadership does not feel comfortable with female pastors such that they are coming up with a ploy to quash the dreams of women aspiring to become pastors. The church should come to terms with the fact that women are also called to minister in God's vineyard. The plan of God cannot be erased by people. The book of the Acts of the Apostles clearly illustrates that God's plan to include the gentiles to become part of his kingdom prevailed despite the resistance put up by the Jews. This is the same with the call of women. Men cannot resist the will of God that women be pastors. It has been always in God's plan to have women in leadership. Moreover, Oduyoye (2001) propounds that partnership of women and men, whether ordained or not is the true image of the church of Christ. That is the reason why a woman was given the power to dominate as well just like a man when we consider what the bible says in Genesis 1:28. However, some have used the same bible to subjugate women because of their gender. It is against this backdrop that Nadar (2005) refers to religion, culture and gender construction as an unholy trinity which conspires against the flourishing of women.

\section{Female pastors not being given an opportunity to preach at national conferences}

One of the major roles of the pastors is to preach to the congregants. Paradoxically, female pastors are being denied the opportunity to preach especially at the national conferences which is supposed to be the pinnacle of their ministry. Such prohibitions might be indicative of the fact that the AFMZ male leadership is still doubting the genuinity of women's calling. This is a reflection of injustice which African women theologians oppose. Kanyoro (2001) avers that any pattern of discrimination is contrary to God's justice. As has been observed in the literature review, women are also candidates for ordination. There is evidence in the bible that women have always been a part of Jesus' ministry even up until the early church period. Consequently, if the AFMZ bases its teaching on the bible, it therefore cannot afford to go against the biblical values. Like Oduyoye (2001) stated, equality was brought by Jesus' death on the cross. Hence, the AFMZ which believes in the death and resurrection of Jesus should be leading in advocating for equality between men and women.

\section{Conclusion}

In this article, it has been highlighted that female pastors are facing a lot of challenges in the church despite the fact that the church is expected to be a safe place in which they will have a sense of belonging. The prevailing structures in the AFMZ expose women to perceive the church as a place where they experience domination and marginalisation such that it becomes a place which they can barely call their 'home'. The main contention presented in this article is that women were also created in the image of God just like their male counterparts. Consequently, women, particularly female pastors in the AFMZ, should be seen as full human beings who must be included in church activities without prejudice. The world is changing so are the dynamics of life. It was an acceptable norm for women in the past not to become pastors and not to be in leadership but events have changed and God opened the door for women to be in leadership and to be ordained as pastors. This door is also open even in the secular world. Women are taking up leadership roles and are successfully executing their duties. For women to completely soar and accomplish their God ordained roles as pastors, they should not be exposed to a lot of resistance in their work 
as is the case in the AFMZ. If given the opportunity to operate freely, female pastors in the AFMZ are capable of achieving more than what they have achieved so far.

\section{Acknowledgements}

The field research for this article was conducted as part of a doctoral research for Terence Mupangwa who is the principal author of this article. The tentative title for the doctoral thesis is 'The place of women in the leadership of the Apostolic Faith Mission in Zimbabwe'.

\section{Competing interests}

The authors declare that they have no financial or personal relationships that may have inappropriately influenced them in writing this article.

\section{Authors' contributions}

T.M. and S.C. contributed equally to this research article.

\section{Funding information}

This research received no specific grant from any funding agency in the public, commercial or not-for-profit sectors.

\section{Data availability statement}

Data sharing is not applicable to this article as no new data were created or analysed in this study.

\section{Disclaimer}

The views and opinions expressed in this article are those of the authors and do not necessarily reflect the official policy or position of any affiliated agency of the authors.

\section{References}

Biri, K., 2013, 'African Pentecostalism and cultural resilience: Zimbabwe Assemblies of God Africa', DPhil, Department of Religious Studies, Classics and Philosophy, University of Zimbabwe, Harare.

Chirongoma, S., 2019, 'Gender discrepancies in Zimbabwean religio-cultural and political leadership: A case study of young Christian women in the Midlands province', paper presented at the University of Zimbabwe Conference under the theme 'Dialoguing Women in Christianity, Islam and African Traditional Religions', University of Zimbabwe, Harare, 01 March.

Chitando, E., 2013, 'Re-opening the canon: the transformation of Shona indigenous religion in the face of HIV/AIDS in rural Zimbabwe', in A. Adogame, M. Echtler \& O. Freiberger (eds.), Alternative voices: A plurality approach for religious studies-essays in honour of Ulrich Berber, pp. 195-210, Vandenhoeck \& Ruprecht, Bristol.

Chivasa, N., 2017, 'Handling of pastoral misconduct and discipline: Evidence from the Apostolic Faith Mission in Zimbabwe church', HTS Teologiese Studies/Theological Studies 73(3), a4518. https://doi.org/10.4102/hts.v73i3.4518

Clifford, A.M., 2001, Introducing feminist theology, Orbis Books, Maryknoll, NY.

Darko, N.M., 2015, 'An analysis of perceptions and attitudes towards female pastors in two districts in the Presbyterian Church of Ghana', Master's thesis, University of Ghana.

Dodo, O., Dodo, G. \& Zihanzu, M., 2017, 'African women in traditional leadership role in Zimbabwe: The case of Shona', African Journal of Democracy and Governance 4, 133-158.
Dube, M.W. (ed.), 2001, Other ways of reading: African women and the Bible, Society of Biblical Literature, Atlanta and WCC Publications, Geneva.

Gabaitse, R., 2012,'Towards an African Pentecostal feminist biblical hermeneutic of liberation: Interpreting Acts 2:1-47 in the context of Botswana', PhD thesis, University of KwaZulu-Natal.

Hinga, T.M., 1992, 'Jesus Christ and the liberation of women in Africa' in M.A. Oduyoye \& M.R.A. Kanyoro (eds.), The will to arise: Women, tradition, and the church in Africa, pp. 183-194, Orbis Books, Maryknoll, NY.

Kanyoro, M., 2001, 'Engendered communal theology: African women's contribution to theology in the 21st century', in N. Njoroge \& M. Dube (eds.), Talitha cum!: Theologies of African women, pp. 36-56, Cluster Publications, Pietermaritzburg.

Kasomo, D. \& Maseno, L.M., 2011, 'A critical appraisal of African feminist theology', International Journal of Current Research 2(1), 154-162.

Kwaramba, J., 2004, 'An investigation into the roles of women in church ministry: A case study of the Apostolic Faith Mission in Zimbabwe', Master's thesis, University of Zimbabwe.

Kwaramba, J. \& Dreyer, Y., 2019, 'Organisational leadership, women and development in the Apostolic Faith Mission in Zimbabwe: A practical theology perspective,' HTS Teologiese Studies/Theological Studies 75(1), a5436. https://doi.org/10.4102/hts. v75i1.5436

Machingura, F. \& Nyakuhwa, P., 2015, 'Sexism: A hermetical interrogation of Galatians 3: 28 and women in the church of Christ in Zimbabwe', Journal of Pan African Studies 8(2), 92-114

Madziyire, A. \& Risinamhodzi, T., 2015, Pentecostal dawn in Zimbabwe: The history and tenets of AFM, The Brand Guy and Associates, Harare

Makaudze, G., 2014, 'Women, wealth generation and property ownership in traditional Shona culture in Zimbabwe', Latin American Report 30(2), 18-29.

Makaudze, G., 2015, 'The power of a mother in Shona milieu', Journal for Studies in Humanities and Social Sciences 4(1-2), 266-276.

Mupangwa, T., 2019, 'The place of women in the leadership of the Apostolic Faith Mission in Zimbabwe', PhD thesis, University of KwaZulu-Natal, Pietermaritzburg.

Murefu, C., 2008, 'Biblical equality in Zimbabwe, Africa', in A.B. Spencer (ed.), Global voices on biblical equality: Women and men ministering together in the church, pp. 70-80, Wipf and Stock, Eugene, OR.

Muringa, T.F. \& Makaudze, G., 2014, 'Tradition or misconception?: Contemporary perceptions about working women in Midlands Province in Zimbabwe', European Journal of Humanities and Social Sciences 29(1), 1536-1553.

Nadar, S., 2005, 'Searching the dungeons beneath our religious discourses: The case of violence against women and the "unholy trinity"', Agenda 19(66), 16-22.

Ndlovu, C., 2018,'The management of the Apostolic Faith Mission in Zimbabwe: A model founded in the Apostolic vision', PhD thesis, North-West University.

Oduyoye, M.A., 1995, Daughters of Anowa: African women and patriarchy, Orbis Books, Maryknoll, NY.

Oduyoye, M.A., 2001, Introducing African women's theologies, Sheffield Academic Press, London.

Oduyoye, M.A., 2004, Beads and strands: Reflections of an African woman on Christianity in Africa, Orbis Books, Maryknoll, NY.

Phiri, I., 1997, Women, Presbyterianism and patriarchy: Religious experience of Chewa women in Central Malawi, CLAIM, Blantyre.

Phiri, I., 2004, 'Southern Africa', in J. Parrat (ed.), An introduction to third world theologies, pp. 137-162, Cambridge University Press, Cambridge.

Radford Ruther, R. (ed), 1996, Women Healing Earth - Third World Women on Ecology, Feminism, and Religion, Ecology and Justice Series, Orbis Books, Maryknoll, NY.

Rakoczy, S., 2004, In her name: Women doing theology, Cluster Publications, Pietermaritzburg.

Reynolds, J.J., 2012, 'A critical analysis of the interpretation of the doctrine of justification by faith alone by the Lutheran Church of Christ in Nigeria, Gongola Diocese', PhD dissertation, University of KwaZulu-Natal.

Russell, L.M., 1987, Household of freedom: Authority in feminist theology, vol. 1986, John Knox Press, Westminster.

Russell, L.M., 2001, 'Hot-house ecclesiology: A feminist interpretation of the church', The Ecumenical Review 53(1), 48. https://doi.org/10.1111/j.1758-6623.2001. tb00072.x

Shaw-Taylor, E., 2013, 'The role of women in the church and in Christ Apostolic Church in particular', Scriptura: Journal for Contextual Hermeneutics in Southern Africa 112(1), 1-13.

Sprong, J.L., 2011, “"For healing and transformation": A feminist ecclesiological study on the gap between gender policy and practice in the Methodist Church of Southern Africa (MCSA)', PhD thesis, University of KwaZulu-Natal.

Togarasei, L., 2016, 'Historicising Pentecostal Christianity in Zimbabwe', Studia Historiae Ecclesiasticae 42(2), 1-13. https://doi.org/10.25159/2412-4265/103

Watson, N.K., 2002, Introducing feminist ecclesiology, Sheffield Academic Press, London. 